\title{
1 ELATIONS BETWEEN TRANSYLVANIA AND THE NORDIC COUNTRIES IN THE 19TH CENTURY AS SEEN IN ROMANIAN PERIODICALS. QUANTITATIVE AND QUALITATIVE ANALYSIS
}

\section{Mihaela Mehedinți}

Babeş-Bolyai University, Romania, E-mail: mihaela_mehedinti@yahoo.com

\section{Acknowledgments}

This paper has been presented at the Second International Conference on Nordic and Baltic Studies in Romania: Black Sea and Baltic Sea Regions: Confluences, influences and crosscurrents in the modern and contemporary ages hosted by the Romanian Association for Baltic and Nordic Studies, Târgoviste, May 20-22, 2011. The research for this paper has been facilitated by the programme Investing in people! Ph.D. scholarship, Project co-financed by the Sectoral Operational Program For Human Resources Development 2007 - 2013. Priority Axis 1. "Education and training in support for growth and development of a knowledge based society" Key area of intervention 1.5: Doctoral and post-doctoral programs in support of research. Contract nr.: POSDRU/88/1.5/S/60185 - "Innovative Doctoral Studies in a Knowledge Based Society" , Babeş-Bolyai University, ClujNapoca, Romania

\footnotetext{
Abstract:

History usually demonstrates that if two areas are remote they tend not to be in contact so often. At a first glance this seems to be the case of 19th century Transylvania's connexions with the Nordic countries, but was this really the case? Or it is more likely that the relations between those two areas were not examined thoroughly enough until now? The present study aims at offering some answers to these important research questions by rendering a comprehensive image of the ways in which Sweden, Denmark, Norway and Finland were portrayed in three largely circulated Romanian periodicals from Transylvania. Based on the quantitative and qualitative analysis of the 623 pieces of news published by Foaie pentru minte, inimă şi literatură, Familia and Gazeta de Transilvania between 1838 and 1919 this paper shows that Transylvanians were rather well informed in what concerned the Nordic countries in the 19 ${ }^{\text {th }}$ century, that they
} 
positively appreciated the literary works that stemmed from this area and that they strongly positioned the Nordic countries within Europe.

\begin{abstract}
Rezumat:
Istoria demonstrează că, de obicei în cazul în care două zone sunt indepărtate, ele tind să nu fie în contact atât de des. La o primă vedere acesta pare a fi cazul conexiunilor din secolul al XIX-lea ale Transilvaniei cu țările nordice, dar a fost, intr-adevăr, acesta cazul? Sau este mai probabil ca relatiile dintre cele două arii să nu fi fost destul de atent examinate până acum? Studiul de față îşi propune să ofere câteva răspunsuri la aceste întrebări de cercetare importante, făcând o imagine cuprinzătoare a modului în care Suedia, Danemarca, Norvegia şi Finlanda au fost prezentate in trei periodice româneşti de mare circulație din Transilvania. Bazate pe analiza cantitativă şi calitativă a 623 de ştiri publicate de către "Foaie pentru minte, inimă şi literatură", "Familia" şi "Gazeta de Transilvania" între anii 1838 şi 1919, acest articol arată că ardelenii au fost destul de bine informați în ceea ce priveşte țările nordice în secolul al XIX-lea, că au apreciat pozitiv operele literare provenite din această zonă şi că integrau cu fermitate țările nordice în interiorul Europei.
\end{abstract}

Keywords: Nordic countries, Transylvania, Romanian periodicals, quantitative and quantitative analysis, 19th century

\title{
Political and cultural contacts between Transylvania and the Nordic countries in the 17th -19 th centuries
}

Although the geographical distance that separates Transylvania and the Nordic countries is considerable, especially for the means of transportation available in the $17^{\text {th }}-19^{\text {th }}$ centuries, these two rather different areas still managed to remain in contact. This long-lived relation was facilitated by both the local and the international political circumstances in which the two entities evolved in the above-mentioned period.

Highlighting the existing connections between Transylvania and the Nordic countries beginning with the $17^{\text {th }}$ century may seem inadequate for a paper that has as its main topic the $19^{\text {th }}$ century. Nevertheless such an approach represents a necessary step in order to delineate the ways in which such older relations constitute prerequisites for manifesting some sort of interest towards another political entity. Finding information about the Nordic countries in $19^{\text {th }}$ century Romanian periodicals is naturally conditioned by mutual acknowledgement. The present paper will demonstrate that, despite what common sense might suggest, Transylvania and the Nordic countries knew and appreciated each other as far back as the $17^{\text {th }}$ century. 


\section{countries \\ Political connections between Transylvania and the Nordic}

From a political point of view, Sweden was the Nordic country that was mostly involved in the power shifts that occurred in the South-Eastern part of Europe beginning with the 17th century. Having "the same goal of straining the Ottoman-Polish relations", 1 although for different reasons, Transylvania's and Sweden's diplomatic services had many intrigues to weave and the international context largely facilitated these reciprocal contacts. Sweden wanted a weak Poland as a means of eliminating the latter's claims to the Swedish throne and Transylvania sought to impede the Polish-Austrian collaboration in order to deprive the Habsburgs' Empire of an important ally against herself. A common goal of involving the Ottoman Empire in the Thirty Years' War further bound the two countries. Moreover, Sweden also desired to intensify its relations to the Turks, an objective that could be accomplished through Transylvania's mediation. ${ }^{2}$

Transylvanian anti-Habsburg projects that were so obvious in the province's relations to Sweden during the Thirty Years' War originated in Gabriel Bethlen's foreign policy views. In an attempt to gain a valuable ally against the Habsburgs' Empire he signed a treaty with the king of Denmark, Christian IV, at 9 December 1625. The alliance will be later announced by the Danish ambassador to the court of England, an act which sought to convince the king of England to contribute to the financial help that Denmark offered Transylvania and that had already reached the sum of 30,000 thalers. $^{3}$

As it had a certain political impact upon its neighbours in the first half of the 17th century, a relatively central European geographical position and a confessional composition that could be relevant in the unfolding of the Thirty Years' War, Transylvania could have obtained some advantages from its implication in the conflict. Therefore Prince Gheorghe Rákóczy I carefully considered Gustav Adolf's proposition for an alliance against the Habsburg Monarchy. Although the Swedish king's offer was made in 1631 it would only materialise a decade later, when one of his generals,

\footnotetext{
1 Tahsin Gemil, Țările române în contextul politic internațional (1621-1672) (Bucureşti: Editura Academiei Republicii Socialiste România, 1979), 37.

2 Ibid., 63-64.

${ }^{3}$ Information about this treaty and about the negotiations between the two Rákóczy princes, on the one hand, and Poland or Sweden, on the other hand, was found in Ion Calafeteanu and Cristian Popişteanu, eds. Politica externă a României: dicționar cronologic (Bucureşti: Editura Ştiințifică şi Enciclopedică, 1986), 72-78.
} 
Tortenson by his name, explicitly asked Rákóczy to get involved in the war as Sweden's (and France's) ally. The negotiations started after this proposal came to an end a year later, on 16/26 April 1643, when the treaty signed at Alba-Iulia stipulated that Transylvania was to receive from her allies 150,000 thalers each year until the end of the war and 3,000 people that were to fight side by side with the troupes provided by Rákóczy. ${ }^{4}$

This collaboration will be reinforced in 1645 by a new alliance treaty signed at Munkacz between Transylvania and France. The latter agreed to covering all the necessary costs for 3,000 soldiers (a task in which Sweden also played a part) and to obtaining the Sultan's approval for Transylvania's participation in the war. As France was not able to meet the second condition, Rákóczy was forced to sign an agreement with the Austrian emperor in 1646. By this arrangement, Ferdinand III obligated the Transylvanian prince to reduce his military force and to stop any aid towards the French and the Swedish.

The possibility of obtaining the Polish throne from the alliance with France and Sweden determined Gheorghe Rákóczy I to seek the help of the Moldavian ruler, Vasile Lupu. But the treaty they signed in 1648 will not be applied as Rákóczy died a month later (11 October 1648). Nevertheless, his successor did not have to wait a long time before he was offered a collaboration proposal from the part of Sweden (1652). As a response to the plan for a future division of Poland, Gheorghe Rákóczy II assured Carol Gustav that he will not support the Polish. Moreover, between 1654 and 1658 the Transylvanian prince managed to convince the Wallachian and Moldavian rulers to join the alliance. ${ }^{5}$ This commitment will serve as a basis for demanding Swedish military assistance during the action conducted by the extra-Carpathian sovereigns against Poland in August 1655.

If until now things seemed rather clear, the situation gets more complicated when the king of Poland offers Gheorghe Rákóczy II the crown of his country in exchange for banning the Swedish (October 1655). A series of negotiations, demands and delays in responding then follows between Transylvania and the two belligerent countries, as Rákóczy wanted to make the most of these complex political circumstances in which he played such an important part. ${ }^{6}$

\footnotetext{
4 Horia C. Matei and others, Istoria României în date (Bucureşti: Editura Enciclopedică Română, 1971), 137.

5 The respective rulers were Constantin Şerban in Wallachia and Gheorghe Ştefan in Moldavia. See Ion Hurdubețiu, Istoria Suediei (Bucureşti: Editura Ştiințifică şi Enciclopedică, 1985), 352.

${ }^{6}$ Calafeteanu and Popişteanu, 77-78.
} 
The decisive moment seems to have been the Swedish offer of a considerable part of Poland's territory completed by Rákóczy's acknowledgement as king. At this point (June 1657), the Transylvanian prince sent four different deputations to Poland asking king Ioan Cazimir to sign a peace treaty with Sweden. But greed and indecisiveness were dearly paid by Gheorghe Rákóczy II as he was defeated at Czerny Ostrow by the Polish-Tartar troops a month later (22 July 1657). The peace treaty signed with this occasion stipulated, amongst other things, the payment of a war indemnity of 1,220,000 thalers, an enormous sum at that time, and the obligation to leave Poland's territory on a specified route. So, Transylvania's involvement in the Swedish-Polish conflicts ended badly for the former and after Rákóczy II's moment of glory the TransylvanianSwedish relations weakened.

Transylvania (and the other two Romanian principalities) will once more become involved in continental matters, although with a brief and less evident participation, on the occasion of the Great Northern War (17001721). The unfolding of the conflict had important repercussions over the political solutions that Moldavia's and Wallachia's rulers chose. As an example, the plan of an anti-Ottoman campaign that was presented to Peter the Great by Constantin Brâncoveanu in 1702 was disregarded by the former due to the ongoing conflict with Sweden. In a similar manner and still because of the Swedish-Russian confrontation, the new Transylvanian prince, Francis II Rákóczy, did not obtain Swedish help against the Habsburgs, ${ }^{7}$ as King Charles XII sacrificed past alliances in favour of present needs. For him, the Austrian Empire's benevolent neutrality towards the Northern War weighted more that supporting a Transylvanian action against the Habsburgs.

The Swedish refusal will determine Francis II Rákóczy to seek help elsewhere. By the alliance treaty signed with Peter the Great on 4 September 1707 he obtained promises for financial and military support in the case of a Swedish attack, for help in obtaining the Principality's independency and for asylum, if needed. In return, Rákóczy obliged himself to try to bring peace between the two belligerents, to avoid making any foreign policy decisions without consulting the tsar and to refuse Poland's throne, in case it was offered to him. But this treaty will not have any consequences.

The Great Northern War will also affect the Romanian Principalities directly, not only by narrowing down their political options. For instance, as it was situated near the Polish war zone, Moldavia's territory was

\footnotetext{
7 Veniamin Ciobanu, Carol al XII-lea şi românii (Iaşi: Domino, 1999), 45.
} 
repeatedly pillaged by the Swedish troops that were quartered here and also suffered the effects of the fights against the Russians, especially after Poltava (1709). .8 Moreover, Mihail Racoviță's and Nicolae Mavrocordat's replacements as successive rulers of Moldavia and Dimitrie Cantemir's enthroning were related to Charles XII's intrigues which sought to involve the Ottoman Empire in a war against Russia. ${ }^{9}$ Such a succession of events was dreaded by the latter, especially if it took place during the conflict with Sweden. Nevertheless, according to his declarations towards Constantin Brâncoveanu, the Wallachia ruler, the tsar only desired to delay (and not completely discard) an eventual attempt to overthrow the Ottoman domination over the Principalities.

The defeat of Poltava had as an effect Charles XII's retreat to Bender (Tighina), on the Ottoman Empire's territory. This will cause large expenses from the part of the Wallachian treasury and a series of political disadvantages stemming from the fortress' transformation into a location of European interest. Moreover, alongside the enormous sums that were spent on providing for the Swedish king and his entourage during their 5 years stay at Bender, their travel back to Sweden was also paid by Romanians. The 50,000 florins that were given to Charles XII right before he entered Transylvania did not come from the treasury of the Habsburgs' Empire, but, ironically, from the fortune of Constantin Brâncoveanu, the former ruler of Wallachia, whose dethronement had something to do with the Swedish king's plots against Russia's sympathisers. ${ }^{10}$

After the end of the Great Northern War, relations between Transylvania and Sweden lessened and the international context also favoured only indirect contacts between the two countries. Losing its status of a great power and becoming neutral in 1815 heavily impacted on Sweden's desires for a central European ally. This tendency of weaker mutual relations can also be remarked in the case of the extra-Carpathian provinces, on the one hand, and the other Nordic countries, on the other hand. For example, the Danish-German dispute over Schleswig and Holstein will only have indirect repercussions for the Romanian principalities, by influencing the European powers' decisions. ${ }^{11}$ And in what concerned the ad-hoc assemblies and the union of the Romanian Principalities (1859), Sweden and Denmark were only secondary decisional

\footnotetext{
${ }^{8}$ L. Boicu, V. Cristian and Gh. Platon, eds. România în relațiile internaționale 1699-1939 (Iaşi: Junimea, 1980), 17.

${ }_{9}$ Ciobanu, 80-91.

10 Ibid., 126.

11 Boicu, Cristian and Platon, 174-184.
} 
factors and their benevolent neutrality towards these political acts did not really help Romanians. ${ }^{12}$

Nevertheless, the Swedish consulates in Bucharest, Galați, Brăila and Constanța and the Romanian corresponding ones in Stockholm, Gothenburg and Malmo ensured some connections between this Nordic country and the Principalities even before Wallachia and Moldavia united. ${ }^{13}$ These relations were further cultivated and Prince Basarab Brâncoveanu was sent in a special diplomatic mission to Stockholm after the Romanian War of Independence. King Oskar II granted him a solemn audience on 24 March/5 April 1879 and Brâncoveanu was able to inform the Swedish king about Romania's newly obtained independency. A similar announcement was made to the king of Denmark, Christian IX, on 2/14 April 1879.14 A few decades later, on 15/25 November 1905, a notification from the opposite direction informed King Carol I of Romania about Norway's peaceful separation from Sweden and about King Haakon VII's enthronement. ${ }^{15}$

In what concerns diplomatic relations at the end of the $19^{\text {th }}$ century and the beginning of the $20^{\text {th }}$ century, a convention for Pacific Settlement of International Disputes was signed at Hague on 17/29 July 1899 by a number of 26 countries, amongst which Romania, Denmark and the United Kingdoms of Sweden and Norway, ${ }^{16}$ and in 1910 two bilateral commercial and navigation conventions were signed between Romania and Sweden and Romania and Norway, respectively. ${ }^{17}$ Diplomatic relations at a level higher than the consular one were to be established only during or after the First World War: in 1916 with Sweden, in 1917 with Denmark and Norway and in 1921 with Finland. 18

\section{Cultural connections between Romanians and Northerners}

Even in the oldest times, the inhabitants of the Nordic part of the continent and those living near the Black Sea had a special relationship. On their commercial routes to Byzantium, the Varangians passed through the area that is nowadays inhabited by Romanians and "took images and fragments of ballads from these parts and carried them to Iceland or

\footnotetext{
12 Ibid., 158.

13 Hurdubețiu, 354.

14 Calafeteanu and Popişteanu, 138.

15 Ibid., 151.

16 Ion Ionaşcu, Petre Bărbulescu and Gheorghe Gheorghe, eds. Relațiile internaționale ale României în documente (1368-1900). Culegere selectivă de tratate, acorduri, convenții şi alte acte cu caracter internațional (Bucureşti: Editura Politică, 1971), 478-502.

17 Calafeteanu and Popişteanu, 154.

18 Matei and others, 302-325.
} 
transmitted them to our old chronicler Saxo Grammaticus. Still they, of course, were the ones that symbolically confused the name of Dacia with the one of Dania and launched it again in the Occident at medieval Sorbonne". ${ }^{19}$ Apparently, these early contacts determined the formation of at least one Scandinavian toponym, but specialists found more proof for the inverse influence. ${ }^{20}$

In the $15^{\text {th }}$ century, Romanians and Northerners will be connected through Nicolaus Olahus' travels in Western Europe. On such a journey he was even able to observe and admire Scandinavians' dexterity in sailing. ${ }^{21}$ A century later, Grigore Ureche's Letopisețul Țării Moldovei (Moldavia's chronicle) mentions (by the name of "şvezi") the Swedish mercenaries hired by Despot Vodă for securing his throne in 1561. ${ }^{22}$ Moreover, the $16^{\text {th }}$ century also records sword-bearer Milescu's journey to Stockholm and the fact that with this occasion the Swedish library enriched its collection with a few Romanian books. ${ }^{23}$

Although in the $17^{\text {th }}$ century the Romanian principalities and the Nordic countries were mainly related from a political point of view, in the $18^{\text {th }}$ century it was the cultural connections that predominated. Even King Charles XII's stay at Bender had not only economical and political repercussions, but also literary ones. For example, Ion Neculce filled tens of pages of his chronicle with information about the Great Northern War, special attention being given to the description of the Poltava battle, to the Swedish king's refuge in the Ottoman fortress, to the negotiations between Charles XII and the Sultan that aimed at the Turks' involvement in the conflict between the Swedish and the Russians and to the foreigners'

\footnotetext{
${ }^{19}$ H. Soerensen, "Studiile româneşti în țările scandinave," Analele Ştiințifice ale Universității "Al. I. Cuza" din Iaşi, New Series, Section III, Tom VI (1960), Fasc. II, Supplement: 57-60. For the Dania-Dacia confusion see also Eugen Lozovan, "De la Mer Baltique à la Mer Noire." In Die Araber in der alten Welt. Zweiter Band. Bis zur Reichstrennung, edited by Franz Altheim, and Ruth Stiehl, 524-554, (Berlin: Walter De Gruyter \& Co, 1965), 532-533.

${ }^{20}$ Lozovan 1965, 537-538. For other examples of Romanian words that might have their origin in Northern Europe see also Eugen Lozovan, "Doina et saga. Parallèles épiques roumano-scandinaves," In Actes du 4 e Congrès des Romanistes Scandinaves dédiés à Holger Sten: Revue Roumane, Numéro Spécial 1 (1967), Tirage à part, 212. These words seem to have been borrowed by the mediation of some Slavic terms, as follows: 'cârd' (flock) could have its origin in the word 'hiro', 'viteaz' (hero) would be derived from 'Viking' and the name 'Iu(r)ga' would have a Nordic correspondent in 'Jørgen'. Moreover, Lozovan finds a series of similar traits of the Romanian 'doina' songs (sad ballads) and the Northern Sagas, both in their heroic content and their literary themes.

${ }^{21}$ Hurdubețiu, 352.

22 Ibid.

23 Soerensen, 57.
} 
relations with the locals. ${ }^{24}$ Radu Popescu and Radu Greceanu, two other chroniclers of the period, also mention Charles XII's presence at Bender, but do not provide so many details as Neculce. ${ }^{25}$ The Swedish troops' passage through the Romanian area seems to have had even architectonic effects, but the tower they built in Bucharest, Coltea Tower, no longer exists. ${ }^{26}$

At the end of the $18^{\text {th }}$ century, a Vocabularium Valahicum is written at Copenhagen and the Danish scholar Rasmus Rasck mentions Romanian amongst the Romance languages. ${ }^{27}$ In 1870 the first exchange relation between the library of the Romanian Academic Society and the Royal Science Society of Copenhagen is established, at the latter's request.28 Moreover, during the last decades of the century, Kr. Nyrop visited Romania and wrote a book that encompassed his travelling impressions. ${ }^{29}$ Nyrop also translated some Romanian literary works into Danish (Miorița, Meşterul Manole, riddles, dirges, ritual cries). ${ }^{30}$

But the appreciation of literature was mutual. A number of Northern authors were well known in Transylvania and Hans Christian Andersen, Henrik Ibsen, Selma Lagerlöf or August Strindberg were just a few of the ones that were acknowledged even during their lifetime. Another Danish erudite, Kr. Sandfeld, wrote a Ph.D. thesis entitled Rumaenske studier (Romanian studies) and published it in 1900.31 Having Sextil Puşcariu, Theodor Capidan and Pericle Papahagi as friends, he was also able to write two other major works, Linguistique balcanique (Balkan linguistics) and Syntaxe Roumaine (Romanian Syntax). As for cultural relations with Sweden, the Swedish-Romanian Society founded in 1929 greatly contributed to their development and consolidation. ${ }^{32}$

The information provided above offers valuable proof in favour of considering that Romanians and Northerners cultivated constant political and cultural relations. These were hindered by geographical distance and by different development routes, but still had a certain impact in the historical evolution of both the Romanian area and the Nordic countries.

\footnotetext{
${ }^{24}$ Hurdubetiu, 353.

25 Ibid., 353-354.

${ }^{26}$ Ibid., p. 354. Colțea Tower is also mentioned by Soerensen, 57.

27 Soerensen, 57-58.

${ }^{28}$ Matei and others, 226.

29 Soerensen, 58. Nyrop's book is entitled Romanske mosaiker (Romanic mosaics).

30 Ibid.

31 Ibid. Other Nordic scholars that have studied the Romanian language are the Danish A. Rosenstand Hansen and Knud Togeby, the Swedish Alf Lombard, Dagmar Falk and Bengt Hasselrot or the Finnish V. Kiparsky.

32 Hurdubețiu, 355.
} 
And the analysis of three $19^{\text {th }}$ century Transylvanian periodicals strengthens this conclusion, as the following sections of this study will show.

\section{Primary sources: Three Romanian periodicals of the $19^{\text {th }}$ century and the information they provide about the Nordic countries}

This study uses three largely circulated and appreciated periodicals of the 19th century in order to unravel the way in which Transylvanians perceived the Nordic countries. Foaie pentru minte, inimă şi literatură (A paper for the mind, heart and literature), Familia (The Family) şi Gazeta de Transilvania (The Transylvanian Gazette) were selected both because they cover the above-mentioned period and because they provide valuable cultural and political information. The first two periodicals are relevant from a cultural point of view, while Gazeta de Transilvania presented in detail foreign and internal political events.

Foaie pentru minte, inimă şi literatură was issued weekly at Braşov between 1838 and 1865. In its first six months of circulation (1 January - 1 July 1838) it was named Foaie literară (A literary paper). ${ }^{33}$ Slight interruptions in its publication were recorded between 1849 and 1865, the latter year being the one that brought about the last two issues of the publication. As the title suggests, this periodical had as a purpose its readers' cultural, spiritual and knowledge enhancement and it tried to achieve this goal by publishing proverbs, aphorisms, biographies, various statistics and literary works. The Nordic countries are mentioned on 9 such occasions during the periodical period of issuance: 3 statistics (one about the ages of the Swedish and Danish Kings, one about the Nordic countries' German inhabitants and the last about the Danish King's enthronement); 3 aphorisms (one pertaining to King Gustav III of Sweden and the other two to his compatriot, Axel Oxenstierna); one literary note regarding the publication of the History of King Charles XII; one historical account about a Romanian soldier in the army of Charles XII that was captured by the Russians after the battle of Poltava, and last but not least, a biographical note on Carl Linnaeus. ${ }^{34}$

\footnotetext{
33 George Em. Marica, Foaie pentru minte, inimă şi literatură. Bibliografie analitică, cu un studiu monografic (Bucureşti: Editura pentru literatură, 1969).

34 The referential information for these articles is: (1) year V, 1842, no. 9, page 72; (2) year XII, 1849, no. 5, pages 37-40; (3) year XII, 1849, no. 7, pages 53-55; (4) year VI, 1843, no. 33, page 264; (5) year XV, 1852, no. 1, page 4; (6) year XVI, 1853, no. 52, page 586; (7) year VIII, 1845, no. 4, page 32; (8) year IX, 1846, no. 10, pages 75-76; (9) year XVI, 1853, no. 18, pages 129-130, respectively.
} 
The first series of Familia appeared between 1865 and 1906 with the full title Familia: Foaie enciclopedică şi beletristică cu ilustrațiuni (The Family: An encyclopaedic and belletristic paper with illustrations) at Pesta (18651880) and Oradea (1880-1906). ${ }^{35}$ The periodical edited by Iosif Vulcan became noticeable by publishing Mihai Eminescu's debut poem, "De-aş avea..." in 1866. Moreover, as the declared intention of Familia was the cultural enrichment of its readers by bringing to their attention a number of literary works pertaining to Romanian or foreign authors, the Nordic writers were not forgotten. As a result, the publication's pages are filled with short stories, novellas, plays, critical studies or cultural statistics that were written by Northerners or that are related to the Nordic countries. Twenty-six such references exist: 16 short stories or novellas, 8 literary or historical studies and 2 statistics. ${ }^{36}$ Alongside these texts, Familia has also published some relevant documentary illustrations. Therefore, Transylvanians were able to see portraits of Fridtjof Nansen (1896, page 517), Henrik Ibsen (1897, page 217), Christian IX, King of Denmark (1897, page 325) or Oscar II, King of Sweden and Norway (1881, page 533; 1897, page 445 , and 1898 , page 73 ).

Gazeta de Transilvania circulated for a longer period than the other two primary sources used in this study. It was first issued at Braşov in 1838 having George Baritiu as editor and continued to appear until the first half of the $20^{\text {th }}$ century, although its name and periodicity varied over time. Between 3 January and 1 December 1849 it was called Gazeta transilvană and after this date it bore the name Gazeta Transilvaniei until December

35 Familia. Foaie enciclopedică şi beletristică cu ilustrațiuni 1865-1906. Indice bibliografic, 2 vols, (Cluj: 1974). See also http://ro.wikipedia.org/wiki/Familia_(revist\%C4\%83), (accessed 11 May 2011). The other series of the periodical have appeared between 1926 and 1928 (second series), 1934 and 1943 (third series), 1944 and 1945 (fourth series), and 1965 to present (fifth series).

36 The literary works of Northern authors can be found in the periodical's following years: (1) 1866, no. 33-37; (2) 1872, no. 31-41; (3) 1875, pages 604-605; (4) 1886, pages 150-151; (5) 1890, pages 258-259; (6) 1897, no. 14, pages 159-160; (7) 1899, no. 26-29; (8) 1900, pages 97-99, 110-112, 121-123, 133-135, 145-147, 157-159, 170-171, 182-184; (9) 1902, page 117; (10) 1902, no. 26 , pages 306-307, no. 27, pages 319-320; (11) 1902, no. 8, pages 90-91; (12) 1904, pages 609610; (13) 1905, pages 318-319; (14) 1906, page 18; (15) 1906, page 187; (16) 1906, pages 174175. The critical studies that provide data about the Nordic countries can be retrieved by using the following references: (1) 1869, pages 241-242; (2) 1881, page 533; (3) 1882, pages 175-179, 191-192, 203-204; (4) 1897, pages 217-219, 234-235, 248-249, 259, 271, 282-284, 295, 307-308, 356, 366-368, 379-380, 390-392, 403-405, 428-429, 439-441, 451-452, 462-465, 476-477, 487-489, 499-500, 511-513, 536-537, 548-549, 560-561, 571-572, 584-585, 596-597, 608-609, 620621; (5) 1900, pages 44-45; (6) 1901, pages 488-489; (7) 1903, pages 222-223; (8) 1906, no. 25, page 295. The two relevant statistics were published in Familia in (1) 1882, page 606 and in (2) 1884, page 265. 
1945.37 At first the gazette appeared on a weekly basis, after a while it started appearing twice a week and since 1884 it was published daily. As it was the first Romanian political newspaper issued in Transylvania, Gazeta referred in its pages to both internal and external events and since it was published for a long period and with a high frequency the information regarding the Nordic countries is rather abundant. From the 711 relevant pieces of news, 699 concern the four Nordic countries (Sweden, Norway, Denmark and Finland) and 12 refer to Iceland and/or Lapland. By eliminating the overlaps in counting the articles, Gazeta de Transilvania provides 588 pieces of news, from which 48 are statistics. ${ }^{38}$ A thorough analysis of these articles about the Nordic countries is provided in the following section.

\section{How were the Nordic countries seen by Transylvanians in the $1^{\text {th }}$ century? A quantitative and qualitative analysis}

As the three periodicals used as primary sources circulated for an extended period of time and had a relatively large audience, it is safe to assume that the information provided by them was constitutive for Transylvanians' image of the Nordic countries. In order to better approximate the way in which the Northern part of the continent was perceived by Transylvania's Romanian inhabitants, the present study combines a quantitative analysis of the pieces of information provided by the three periodicals with a qualitative interpretation of this relevant data. Moreover, as the number of articles found in Gazeta de Transilvania is disproportionately larger than the one of references to the Nordic countries made in Foaie pentru minte, inimă şi literatură and Familia, the political cultural dichotomy previously used in this study was tacitly combined with the quantitative analysis.

\section{Quantitative analysis}

Knowing how many articles about the Nordic countries were available to Transylvanians is very important, as it demonstrates the readers' interest towards such news and it establishes the degree in which this European area was known by the Romanians from Transylvania. Besides, the number of articles on a certain topic is relevant for inferring the

\footnotetext{
37 For details, see http://ro.wikipedia.org/wiki/Gazeta_de_Transilvania, (accessed 11 May 2011).

38 Since the number of references is extremely large, the relevant data for retrieving the mentioned articles will not be provided here, but the information is available upon request.
} 
type of information about the Nordic countries that was preferred by Transylvanians.

The quantitative analysis was conducted separately for each of the three periodicals and the news items provided about each of the four Nordic countries was counted by category (political, cultural or 'various'). The number of statistics provided by the newspapers was also taken into account, as Transylvanians seem to have enjoyed such information in the 19th century. Even though Lapland and Iceland were not included amongst the four Nordic countries, the pieces of news about these areas were also counted, due to their potential comparative value.

In the case of Gazeta de Transilvania two other ways of grouping the articles were used, one by the year in which the articles appeared and the other by the column under which the news were published. Obviously, the fact that certain columns changed their names in time was taken into consideration. For instance, the category that was named 'News' ('Ştiri') included the following columns: 'Mixed news' ('Ştiri mestecate'), 'Chronicle' ('Cronică'), 'Foreign chronicle' ('Cronică străină'), 'External chronicle' ('Cronică externă), 'Everywhere' ('Peste tot'), 'Outside chronicle' ('Cronica din afară'), 'From the outside' ('Din afară'), 'The political events' chronicle' ('Cronica evenimentelor politice'), 'News of the day' ('Ştirile zilei'), 'The day's chronicle' ('Cronica zilei'), 'The political chronicle' ('Cronica politică'), 'The political review' ('Revista politică'), 'From abroad' ('Din străinătate'), 'News' ('Ştiri'), and 'Minor news' ('Ştiri mărunte'). The 'Feuilleton' category included the literary works and articles that appeared in the 'Transylvanian Gazette's Feuilleton' ('Foiletonul Gazetei Transilvaniei') and the 'Various' category encompassed the pieces of news that were published in the 'Various' ('Diverse') and 'Many and every' ('Multe şi de toate') columns. The 'Telegrams' category refers to the 'Telegraphic news (Partial Service of the Transylvanian Gazette)' ('Ştiri telegrafice (Serv. Part. al «Gaz. Trans.»)'), 'The Transylvanian Gazette's Telegrams' ('Telegramele «Gaz. Trans.»'), 'Latest news' ('Ştiri ultime'), and 'The latest pieces of news' ('Ultime ştiri'). A final category that was used for analysing the information that Gazeta de Transilvania provided about the Nordic countries during the $19^{\text {th }}$ century was 'Stand-alone news' and it included the relevant articles that did not appear under one of the periodical's columns.

Alongside creating exhaustive and disjunctive categories, the validity of the analytical approach was also ensured by the rules used when including the articles into a category or another. For instance, the 'political' category encompassed information about the Nordic sovereigns' ages, marriages, visits to other monarchs, deaths and murder attempts that had them as a target. Nevertheless, the 'cultural' and 'various' categories 
included articles that referred to the same kings and queens but had a different content. The aphorisms published in Foaie pentru minte, inimă şi literatură or in Familia and information about the expeditions conducted by Nordic explorers were counted under the 'various' category. Articles about the Nobel prizes and about literary works pertaining to Northern authors constituted a part of the 'cultural' category.

Some overlaps emerged as a result of the fact that a part of the pieces of news contained information about two or more of the Nordic countries, and these articles were counted repeatedly, for each Nordic country they mentioned. This happened mainly, but not exclusively, in the case of statistics, which were taken into consideration on a stand-alone basis, overlooking the article's previous inclusion into a certain category by country or by column.

The tables presented below (tables 1-6) summarise the number of news provided by the three Romanian periodicals, in accordance with the counting rules and observations that were listed above.

a) Foaie pentru minte, inimă şi literatură

\begin{tabular}{|l|c|c|c|c|c|}
\hline $\begin{array}{c}\text { Country } \\
\text { Category }\end{array}$ & Sweden & Finland & Denmark & Norway & Total \\
\hline Political & 1 & - & 1 & - & 2 \\
\hline Cultural & 1 & - & - & - & 1 \\
\hline Various & 6 & - & 2 & 1 & 9 \\
\hline Total & 8 & 0 & 3 & 1 & 12 \\
\hline
\end{tabular}

Table 1: Distribution of articles about the Nordic countries published in Foaie pentru minte, inimă şi literatură by country and by news category

\begin{tabular}{|c|c|}
\hline Country / Category & Number of articles \\
\hline Lapland & - \\
\hline Iceland & - \\
\hline Statistics & 3 \\
\hline
\end{tabular}

Table 2: Number of articles about Lapland or Iceland and number of statistics published in Foaie pentru minte, inimă şi literatură

It is easily noticeable that in the pages of this periodical only 12 pieces of news about the Nordic countries were published, 3 of them being statistics. This number differs from what was previously noted when 
presenting the primary sources due to the above-mentioned overlaps, as some articles refer to two or more of the Nordic countries.

b) Familia

\begin{tabular}{|l|c|c|c|c|c|}
\hline $\begin{array}{c}\text { Country } \\
\text { Category }\end{array}$ & Sweden & Finland & Denmark & Norway & Total \\
\hline Political & 2 & - & 2 & - & 4 \\
\hline Cultural & 8 & 1 & 8 & 6 & 23 \\
\hline Various & - & - & 1 & - & 1 \\
\hline Total & 10 & 1 & 11 & 6 & 28 \\
\hline
\end{tabular}

Table 3: Distribution of articles about the Nordic countries published in Familia by country and by news category

\begin{tabular}{|c|c|}
\hline Country / Category & Number of articles \\
\hline Lapland & - \\
\hline Iceland & - \\
\hline Statistics & 2 \\
\hline
\end{tabular}

Table 4: Number of articles about Lapland or Iceland and number of statistics published in Familia

For Familia, there are 28 relevant articles, from which 2 are statistics. Two overlaps of the kind that was already mentioned occurred here also and therefore the real number of pieces of news concerning the Nordic countries for this periodical is 26 .

c) Gazeta de Transilvania

\begin{tabular}{|l|c|c|c|c|c|}
\hline $\begin{array}{c}\text { Country } \\
\text { Category }\end{array}$ & Sweden & Finland & Denmark & Norway & Total \\
\hline Political & 91 & 34 & 133 & 77 & 335 \\
\hline Cultural & 53 & 6 & 30 & 36 & 125 \\
\hline Various & 84 & 9 & 73 & 73 & 239 \\
\hline Total & 228 & 49 & 236 & 186 & 699 \\
\hline
\end{tabular}

Table 5: Distribution of articles about the Nordic countries published in Gazeta de Transilvania by country and by news category 


\begin{tabular}{|c|c|}
\hline Country / Category & Number of articles \\
\hline Lapland & 7 \\
\hline Iceland & 5 \\
\hline Statistics & 48 \\
\hline
\end{tabular}

Table 6: Number of articles about Lapland or Iceland and number of statistics published in Gazeta de Transilvania

Apparently Gazeta de Transilvania published 711 relevant articles about the Nordic countries between 1838 and 1919 (699 pieces of news about the four Nordic countries and 12 pieces of news about Lapland and Iceland), from which 48 are statistics. But overlaps are numerous for this periodical and therefore the total number of articles is actually 588 .

According to the appearance year, these 588 articles are distributed as shown in the table presented below (table 7).

\begin{tabular}{|l|l|l|l|l|l|}
\hline Year & $\begin{array}{c}\text { Number } \\
\text { of articles }\end{array}$ & \multicolumn{1}{|c|}{ Year } & $\begin{array}{c}\text { Number } \\
\text { of articles }\end{array}$ & \multicolumn{1}{|c|}{ Year } & $\begin{array}{c}\text { Number } \\
\text { of articles }\end{array}$ \\
\hline 1838 & 1 & 1866 & - & 1894 & 3 \\
\hline 1839 & 1 & 1867 & 1 & 1895 & 5 \\
\hline 1840 & 4 & 1868 & 3 & 1896 & 21 \\
\hline 1841 & 2 & 1869 & 1 & 1897 & 3 \\
\hline 1842 & 1 & 1870 & 2 & 1898 & 9 \\
\hline 1843 & - & 1871 & - & 1899 & 14 \\
\hline 1844 & 9 & 1872 & - & 1900 & 6 \\
\hline 1845 & 2 & 1873 & - & 1901 & 18 \\
\hline 1846 & 9 & 1874 & - & 1902 & 13 \\
\hline 1847 & 1 & 1875 & - & 1903 & 5 \\
\hline 1848 & 7 & 1876 & - & 1904 & 9 \\
\hline 1849 & - & 1877 & - & 1905 & 41 \\
\hline 1850 & - & 1878 & - & 1906 & 30 \\
\hline 1851 & 1 & 1879 & 4 & 1907 & 34 \\
\hline 1852 & 1 & 1880 & 1 & 1908 & 9 \\
\hline 1853 & 1 & 1881 & 3 & 1909 & 27 \\
\hline 1854 & 1 & 1882 & - & 1910 & 14 \\
\hline 1855 & 10 & 1883 & 6 & 1911 & 7 \\
\hline 1856 & 5 & 1884 & 17 & 1912 & 25 \\
\hline 1857 & 6 & 1885 & 16 & 1913 & 18 \\
\hline 1858 & - & 1886 & 4 & 1914 & 22 \\
\hline
\end{tabular}




\begin{tabular}{|l|l|l|l|l|l|}
\hline 1859 & 1 & 1887 & 7 & 1915 & 16 \\
\hline 1860 & - & 1888 & 14 & 1916 & - \\
\hline 1861 & - & 1889 & 9 & 1917 & 1 \\
\hline 1862 & - & 1890 & 3 & 1918 & - \\
\hline 1863 & 11 & 1891 & 23 & 1919 & 4 \\
\hline 1864 & 36 & 1892 & 3 & & \\
\hline 1865 & 3 & 1893 & 4 & Total & $\mathbf{5 8 8}$ \\
\hline
\end{tabular}

Table 7: Yearly distribution of news about the Nordic countries published in Gazeta de Transilvania

The distribution of the articles by column is presented below (table $8)$.

\begin{tabular}{|c|c|}
\hline Column & Number of articles \\
\hline News & 303 \\
\hline Various & 85 \\
\hline Stand-alone news & 68 \\
\hline Feuilleton & 67 \\
\hline Telegrams & 65 \\
\hline
\end{tabular}

Table 8: Distribution of news about the Nordic countries published in Gazeta de Transilvania by column

Many of these pieces of news are thematically connected and therefore a rather large number of references to the same Nordic country appear in the same year or in a short period of time. Moreover, these related articles tend to be published in the same column. Examples of such repetitive political references include 16 pieces of news about Finland that concern the Russification policy led by the Tsarist Empire in this country and 63 articles about Denmark that inform Transylvanians about the Schleswig-Holstein Question. Fourteen articles cover the Kronstadt rebellion and 10 other refer to the Swedish general strike of 1909.

The dissolution of the union between Sweden and Norway is also largely treated in Gazeta de Transilvania's pages, as part of different columns. Thus, from the 30 articles that concern this issue, 20 are 'standalone news', 6 are 'telegraphic news' and 4 were included in the category that was simply called 'news'.

The political actions of the Norwegian writer Bjørnstjerne Bjørnson against the Magyar rulers of the Austro-Hungarian Empire were 
mentioned 11 times in the pages of the Transylvanian periodical, 8 times as 'stand-alone news' and 3 times as 'news'. Information about Bjørnson's health status was also published in 9 articles of Gazeta de Transilvania, and these were included amongst the cultural news about Norway.

As a result, without counting the overlaps, but taking into consideration the times when an article or literary work was published repeatedly 39 , the quantitative analysis shows that a total of 623 pieces of news about the Nordic countries appeared in the three periodicals that served as primary sources for this study. ${ }^{40}$ This number is rather large, even when taking into consideration the fact that these articles appeared between 1838 and 1919. Therefore, in spite of what many would think, in the $1^{\text {th }}$ century and at the beginning of the $20^{\text {th }}$ century, Transylvanians knew a lot about the events that took place in the Nordic countries and appreciated the literary works of Northern authors. But one cannot get an accurate image of the ways in which Transylvanians perceived the Nordic countries in the $19^{\text {th }}$ century only by counting on this simple remark. Hence this quantitative analysis is followed by a qualitative one.

\section{Qualitative analysis}

From a qualitative point of view, the news about the Nordic countries is extremely diverse. In the first half of the 19th century, the relevant pieces of information are representative especially from a cultural perspective, as they are mainly translations of literary works pertaining to Northern authors. But in time the articles that refer to the North of Europe diversify and Transylvanians get information about the latest political

\footnotetext{
39 There were 11 such instances: a quote from Oxenstierna was published twice in Foaie pentru minte, inimă şi literatură (1852, no. 1 and 1853, no. 52); Onkel Adam's novella 'The Golden Chain' ('Lanțul de aur') appeared twice in Familia (1866 and 1899); Hans Christian Andersen's 'The Story of a Mother' ('Istoria unei mame') first appeared in Familia (1875) and was then published three times in Gazeta de Transilvania (1891, 1902 and 1905); another one of his stories, 'The Naughty Boy' ('Băiatul răutăcios'), was published twice by Familia (1886 and 1906); 'A habit that should be followed' ('Un obicei de imitat'), an article about the tests that Norwegian girls had to pass before being allowed to get married, was published three times in Gazeta de Transilvania (1883, 1885 and 1887); a story by Selma Lagerlöff was published twice, under different names, as 'The Holly Night' ('Noaptea Sfântă') in Familia (1904) and as 'The Caesar's vision' ('Vedenia Cezarului') in Gazeta de Transilvania (1910); and, last but not least, two novellas written by Bjørnstjerne Bjørnson, 'The Father' ('Tatăl') and 'Fidelity' ('Fidelitate') were published twice each, the first in Familia (1906) and then in Gazeta de Transilvania (1907) and the second in Gazeta de Transilvania (1896 and 1907).

40 Unfortunately, only the number of articles about the Nordic countries that were published in the three Transylvanian periodicals is available. The exact percentage of these articles as compared with the rest of the periodicals' content could not be calculated, but it should be considered smaller than 5\%. Thank you Stefan Ewert for this methodological observation.
} 
changes in the Nordic countries, about the scientific or geographic discoveries made by Northerners or even about the development of certain economic sectors. The latter type of news is mainly provided by the statistics that Transylvanians seem to have appreciated so much.

The above statements refer mainly to Gazeta de Transilvania. This periodical differs from Foaie pentru minte, inimă şi literatură and from Familia by the fact that it appeared regularly, during a significantly longer period of time and with a rate of issuance that grew progressively. Therefore there was more and more space in its pages for approaching various themes and for offering details that might have been disregarded by a periodical with a lower rate of appearance.

News about the Nordic countries fits this description, as it did not provide vital information to Transylvanians. Nevertheless, because the available space allowed it, articles about the Nordic countries become more and more frequent and consistent. Besides, the journalists found it ever easier to be knowledgeable about any political event of the international scene, even though not always directly. Thus, many articles published by Gazeta de Transilvania were (translations and) reprints from other newspapers, either Romanian or foreign, as the prestigious The Times or Berliner Zeitung. These publications usually had reporters that travelled to the scene and gave accurate information about the events that they referred to. As they did not have the same financial resources, Transylvanian journalists confined themselves to further transmitting the desired news from these periodicals to their Romanian readers, although not uncritically, but by adapting it to their public. Therefore these articles were usually completed by Gazeta de Transilvania's journalists with one or two paragraphs in which they expressed their own opinion about the piece of news they had just reported on and sketched the implications that this particular information could have for their co-nationals. Nevertheless, situations in which news is 'borrowed' without further commentaries also exist, especially if that information did not have a strong impact upon the Romanian area.

This progressive growth of references to the Nordic countries was due to the increase of issuance rates, of the number of political news published by Gazeta de Transilvania, and of their more thorough consideration. But this was not a phenomenon that applied only to the Northern part of Europe, but also to other geographical areas. Therefore, Transylvanians were also well informed about some Asian states (especially India and China), the African continent, North America (mostly the United States of America, as European emigration statistics are relatively frequent), and even Mexico or Brazil. From this point of view, the 
Transylvanian periodical played an important part in providing valuable news about the political evolutions of these areas, about scientific discoveries made in faraway lands, about literary works of foreign authors, about the habits, customs and traditions of various peoples. One could easily say then that this newspaper served its readers not only as a means of spending spare time, but also by educating them through the provision of knowledge about other peoples' culture and civilisation. Moreover, it tacitly promoted the idea of diversity, its acceptance and valorisation.

As for the periodicals' readers, it must be noted that the number of literate people was small in the 19th century. Thus, even though in Transylvania the situation was not as bad as in Wallachia or Moldavia (due to the Austrian enlightened absolutism and to the measures taken by the Hungarian rulers), large deficiencies still existed. Nevertheless, many illiterate Romanians had an indirect access to the information provided by the periodicals: the ones that could read did so aloud to groups of relatives, friends and acquaintances.

The readers' origin is also relevant for a well conducted analysis. Therefore it is important to mention that most of the periodicals' subscribers lived in urban areas, where the rate of educated persons was higher than in the rural ones. Moreover, Foaie pentru minte, inimă şi literatură and Familia had an even smaller circulation, mainly amongst the urban elites, as they were strictly oriented on cultural topics.

Nevertheless, even though not all Transylvanians could read and from the ones that could do so not all had access to newspapers, one might still conclude that the relevant news reached a fairly large number of people. This happened primarily through the information diffusion process described above. Furthermore, according to the laws of social psychology, it is safe to assume that images of certain peoples, such as the Nordic ones, were even more widespread, through legends and stories that probably contained only a small portion of the truth and that circulated amongst Romanians from father to son. This statement is valid especially in Wallachia's case, where Charles XII's passage left durable impressions on the collective mentality ${ }^{41}$, but can also be considered as well-founded for Transylvania if we refer to the two Rákóczy princes that were involved in the continent's problems during the 17th century. Moreover, the total lack or the scarcity of information is one of the main factors involved in the propagation and perpetuation of ethnic stereotypes.

The terminology used when referring to the Nordic countries also generates interesting observations as the names by which the Northern

41 See Ciobanu, 127. 
kingdoms are designated vary over time. Sweden appears as Sfezia, Svedia or Svetia and Denmark is sometimes denominated Danimarca or Danimarka, but it is most often called Dania. Even more intriguing is the fact that the names for Norway or Finland are used with much more consistency and this is also true for the capitals of the four Nordic countries. The reasons that such toponymical variations exist or do not occur are probably connected to the Romanian language's evolution during the $19^{\text {th }}$ century and to the ways in which the Nordic countries were designated in foreign periodicals. Probably the names of Norway, Finland and all the four Northern capitals were more uniformly spelled in Occidental languages and the words used by Romanian journalist echo this peculiarity.

Still from a terminological point of view, it is important to mention that the word 'Scandinavia' was used in a specific manner by the three Romanian periodicals. Apparently, for $19^{\text {th }}$ century Transylvanians this term had a narrower meaning than was is usually ascribed to it nowadays, as it designated only Sweden and Norway and not all of the Nordic countries. Probably this option was due to a higher importance granted to its geographical meaning, as opposed to its cultural or civilisation-related implications.

Another general qualitative observation that stemmed from reading the relevant articles printed by Foaie pentru minte, inimă şi literatură, Familia and Gazeta de Transilvania is the fact that the information about the Nordic countries is customary rather short and placed in the second part or even at the end of the foreign news column. This is a perfectly explainable option of the Romanian journalists if one takes into consideration the frequency and the significance of direct relations between Transylvanians and the Northern part of Europe in the 19th century. Nevertheless, it should also be noted that in spite of their brevity and positioning, the articles about the Nordic countries cover the essence and accurately and promptly inform Transylvanians about any political changes or cultural developments that occurred in this area. The royal marriages, divorces, deaths or life threatening experiences, the Nordic sovereigns' visits to Romania or other European states, the geographical and scientific discoveries that took place in the North, the deaths of renowned Northerners and other territorial or political changes in the Nordic countries are noted and sometimes commented on.

Although this is the general tendency, in the pages of Gazeta de Transilvania major political events from the Nordic countries receive more coverage space, are sometimes printed on the first page of the periodical and change their status from a part of the foreign news column to 'standalone news'. This happened for instance in the case of major changes in the 
Schleswig-Holstein Question, at the moment that Norway proclaimed its independency from Sweden in 1905, during the legislative changes operated by the Tsarist Empire in Finland in its attempt to Russianise the country or when Bjørnstjerne Bjørnson made harsh declarations against the Magyarisation policies adopted in the Austro-Hungarian Empire. Moreover, new details on these topics appeared in every issue of the periodical, until a solution to the problem was found. Most of the times such events also caused significant increases in the number of articles about the Nordic countries published in that particular year. ${ }^{42}$

Such a 'journalistic' inclination is extremely visible in the case of information provided about Finland. This is scarce as compared with the number of articles about the other Nordic countries, especially when referring to political news. ${ }^{43}$ Foaie pentru minte, inimă şi literatură does not provide any information about Finland, Familia offers only one relevant piece of news and Gazeta de Transilvania 49 articles, a small number compared with the correspondent data for the other three Nordic countries: 186 articles for Norway, 228 for Sweden and 236 for Denmark. Moreover, a third (16) of these 49 pieces of news about Finland covers the Tsarist Empire's Russification policy and these 16 articles represent almost half of the 34 political articles regarding this country. Clearly, an inclination towards offering details on a certain topic exists, especially if this topic has some relevance to Romanians as it happens in this particular case: not only Finland, but also the extra-Carpathian provinces suffered from some of the harsh measures adopted by the Russian Empire during its expansion towards the West.

As was noted in the quantitative part of the analysis, not every issue of Gazeta de Transilvania contains information about the Nordic countries. Sometimes, a whole year passes without such news. Publishing articles about the Northern part of the continent is strongly related to changes in the internal structure of these countries and/or to their international actions. It becomes obvious then why news about Finland and Norway is less numerous than that about Sweden and Denmark, as the first two countries were not independent during the 19th century.44 Moreover,

\footnotetext{
42 See above, the Quantitative analysis section.

43 See above, the Quantitative analysis section. Unfortunately, I have no knowledge about a similar analysis made for $19^{\text {th }}$ century Hungarian periodicals from Transylvania. It is possible that they provide more information about Finland, either from a political point of view or from a cultural one, due to the similarities between the two peoples. Thank you Bogdan Murgescu for this observation.

44 Finland was a province of the Swedish Empire until 1809 when it is conquered and administrated by the Russian Empire as an autonomous Great Duchy until 1917. Norway
} 
Transylvania's own internal and external evolutions also greatly influence the number and consistency of the pieces of news about the Nordic countries published in Gazeta de Transilvania. Changes in the province's status sometimes totally eclipse news about other areas, including Northern Europe. The 1848 revolution or the diets' convocation during the 1860s are the most relevant examples, but not the only ones. As these events unfolded only a few other pieces of information managed to get coverage in the periodical. Moreover, due to the fact that no major modifications took place in the Nordic countries in this period, information about them is scarce. This phenomenon is perfectly normal and explainable, as a newspaper's role is to inform and the topics it chooses are the ones which have the most relevance to its readers.

An evolution of the news about the Nordic countries can also be remarked when one considers the additional explanations provided to the readers alongside the main content of the articles. In the first half of the $1^{\text {th }}$ century such supplementary details about the Nordic countries are common, but they tend to gradually disappear in time. Due to these references one can infer the depth of the Transylvanians' knowledge about the Nordic countries, both in what concerns their internal affairs and their alliances and international interests. In the second half of the century, the articles published by the periodicals almost never contain such explanatory notes and mentioning Northern cultural personalities no longer requires details about their home countries: the mere record of their nationality is sufficient.

Still from a cultural point of view, an evolution in the case of translations from Northern authors is also apparent. If at first Transylvanians opted for translating these texts from internationally circulated languages (especially French), in time explicit specifications refer to the fact that the literary works were translated directly from Swedish or Danish. Unfortunately, most of the times such details are not available and therefore the percentage of translations from the original version of the texts cannot be calculated.

Increases in the frequency of references to the Nordic countries and to some Northern personalities also bring about some stereotypical phrases used in articles with connected topics. These expressions were used as explanatory appositions or in order to avoid repetitions, but they also testify to the fact that the readers already possessed some information about the discussed subject. The most representative stereotypical formulas

was a Danish province until 1814 when it was ceded to Sweden to which it belonged until 1905. 
used by the Transylvanian periodicals are 'the great/renowned (Nordic/polar) explorer', an expression that was used to designate, among others, Fridtjof Nansen, Sven Hedin and Nils Adolf Erik Nordenskiöld, and 'a (small and) tenacious people', with reference to the Finnish and their fight against Russification.

Another general observation is that Transylvanian periodicals mainly covered the contemporary events related to the Nordic countries. Thus, although some historical references exist, 45 they are rare and have a purely literary and/or contextual value. ${ }^{46}$ The attention given by the newspapers to reporting on the current state of affairs stemmed from the need to inform their readers about the latest political news or scientific and geographical discoveries.

Sometimes, 19th century Transylvanians knew more than what was retained by posterity. Thus, although most of the Northern personalities mentioned by the three periodicals were scientists, explorers and writers renowned worldwide, ${ }^{47}$ some of them did not gain such post-mortem appreciation. Such examples are 'the renowned explorer Nordens-Kijöld', the Danish writers Vilhelm Bergsøe and G. Wied or the Finnish author Pietari Päivärinta.

A last but very important aspect that needs to be discussed as part of this study is Transylvanians' image of the Nordic countries. The impression given by the articles published by the three periodicals is that they did not consider them atypical or placed at a distant border. On the contrary, every time they are mentioned, the Nordic countries appear as an important part of Europe, both from a cultural point of view and from a geographical one. Therefore, although the phrase 'Nordic countries' is frequently used, they do not seem marginal, unfamiliar or distant. The information provided by the Romanian travellers to this area further sustains this affirmation, as their reports of visits to Sweden or Denmark do not qualitatively differ from the impressions they note when passing through France or England.48 Another argument for considering that

\footnotetext{
45 See, for instance, the historical sketch about the Thirty Years' War that appeared in 1882 in Familia, pages 175-179, 191-192, and 203-204.

46 One of the best such examples is the story which describes how Petru Crasan, a Romanian volunteer in Charles XII's army, was captured by the Russian army. The text published in Foaie pentru minte, inimă şi literatură, no. IX, pages 75-76 does not fail to mention the courage displayed by the Romanian soldier when faced with Tsar Peter the Great.

47 For instance, Carl von Linné, Alfred Nobel, Selma Lagerlöff, Georg Brandes, Hans Christian Andersen, Henrik Ibsen, Bjørnstjerne Björnson, Fridtjof Nansen and Roald Amundsen.

48 See 'A letter from Sweden' ('O scrisoare din Suedia'), an article sent by G. Moianu to the director of Gazeta de Transilvania and published in its pages in 1893, no. 186, and the essay
} 
Transylvanians saw the Nordic countries as a part of Europe is the content of the relatively large number of statistics that were published by the three periodicals ( 3 by Foaie pentru minte, inimă şi literatură, 2 by Familia and 48 by Gazeta de Transilvania). These statistics include Sweden, Denmark, Norway and Finland amongst the other European countries, without any differentiations.

In conclusion, both the quantitative and the qualitative analysis of the articles used as primary sources show that Transylvania's Romanian inhabitants were well informed about the events that took place in the Northern part of the continent and also knew a lot about cultural personalities originating in this area. Moreover, they perceived the Nordic countries in a positive light, especially when it came to literary works. These were published in relatively large numbers during the $19^{\text {th }}$ century. From a political point of view, the Nordic countries were considered European and therefore close to the Romanian area. Geography, culture and civilisation converged to sustain this impression.

\section{Concluding remarks: Transylvania and the Nordic countries in the $19^{\text {th }}$ century}

This study's objective was to discover 19th century Transylvanians' image of the Nordic countries. In order to do so, presenting the history of relations between these two areas was an indispensable step. This approach led to the conclusion that in spite of what one would think Transylvania's political and cultural connections to the Nordic countries were rather well developed, at least from the $17^{\text {th }}$ century onwards.

The next section of the study presented the primary sources used in order to ascertain how Romanians inhabiting the intra-Carpathian area perceived the Northern part of the continent. Thus, relevant articles published by three largely circulated Transylvanian periodicals of the $19^{\text {th }}$ century were carefully scrutinised. Foaie pentru minte, inimă şi literatură and Familia were chosen in order to provide cultural information about the Nordic countries, whereas Gazeta de Transilvania offered the necessary political data.

The pieces of news that referred to the North of Europe were selected and then quantitatively and qualitatively analysed. As Gazeta de Transilvania provided over $94 \%$ of the articles of interest, the three periodicals were examined separately. News was categorised by country (Sweden, Finland, Denmark or Norway) and by the type of information it

'From the life of a Danish village' ('Din viața unui sat danez') written by Dumitru Brezulescu and published by Familia in 1903, pages 222-223. 
contained (political, cultural or various). Clear-cut rules were set in order to consistently include the articles in the given categories and to avoid any ambiguous situations.

News about Lapland and Iceland was also taken into consideration, although they were not included amongst the Nordic countries. The information provided by this assessment had only a comparative value and served as a complement of the main findings, as did the number of statistics published by the three Transylvanian periodicals. The latter were also counted separately, as they proved to be rather frequent.

The results obtained for Foaie pentru minte, inimă şi literatură were not spectacular as this periodical only published 12 pieces of news about the Nordic countries during its 27 years of issuance (1838-1865). These articles were distributed as follows: 8 pieces of news about Sweden, 3 about Denmark and 1 about Norway. Amongst these 12 articles, 2 had political content, 1 was culture-related, 9 were included in the various category and 3 were statistics.

Familia printed a slightly larger number of news about Northern Europe, partly because it appeared for a longer period of time (1865-1906). The total of 28 relevant articles, amongst which 2 were statistics, covers all of the four Nordic countries, as 11 are about Denmark, 10 about Sweden, 6 about Norway and 1 about Finland. As for their content, 4 pieces of news were political, 23 cultural and 1 was counted under the various category.

Due to its longevity (1838-1919) and to its higher frequency of issuing (it became a daily periodical after 1884), Gazeta de Transilvania provided 588 articles of interest. Amongst these, 236 pieces of news refer to Denmark, 228 to Sweden, 186 to Norway and 49 to Finland. By content, 335 articles cover political events, 125 are cultural ones and 239 pertain to the various category. Unlike the two afore-mentioned periodicals, Gazeta de Transilvania also found place in its pages for information about Lapland (7 articles) and Iceland (5 articles). Moreover, the number of statistics published by this newspaper is also higher than in the other two periodicals: 48 . The yearly distribution of the relevant pieces of news shows that their number varies between 0 and 41 , in relation to the events that took place in the Nordic countries. The articles' repartition by column clearly shows the periodical's aim of providing political information: 303 news, 68 stand-alone news and 65 telegrams, on the one hand, and only 85 various articles and 67 literary works published in the feuilleton, on the other hand.

The total of 623 articles published by the three Romanian periodicals between 1838 and 1919 was further analysed qualitatively, an undertaking that produced interesting results. For instance, it showed that 
translations represent the largest part of the cultural data about the Nordic countries that appeared in the Transylvanian periodicals. Works of internationally recognised authors such as Selma Lagerlöff, Georg Brandes, Hans Christian Andersen, Henrik Ibsen and Bjørnstjerne Bjørnson were published in Romanian, after being translated from French or from their original language. As for political news, renowned European publications like The Times or Berliner Zeitung served as sources for most articles, even though sometimes commentaries pertaining to the Romanian journalists are also added.

The numerical increase in pieces of information about the Nordic countries which took place towards the end of the $19^{\text {th }}$ century is a phenomenon that can be described for other areas as well. Therefore, Transylvanians had at their disposal picturesque details about all of the continents, in what concerns political changes, customs, traditions or habits of other peoples.

With regard to the terminology used when referring to Northern Europe it must be noted that it varied over time, at least in the case of Sweden and Denmark. The former was successively designated by 'Sfezia', 'Svedia' and 'Sveția' and the latter was called 'Danimarca', 'Danimarka' and 'Dania'. Moreover, throughout the $19^{\text {th }}$ century 'Scandinavia' referred only to the dynastic union between Sweden and Norway.

The frequency of explanatory notes on the Nordic countries also changes over time and from their numerical decrease one can infer that Transylvanians knew more and more about this part of the continent towards the end of the century. This observation could be connected to what was already noted regarding the number of articles about the Nordic countries taken in consideration on a temporary scale. Therefore, it can be asserted that Transylvanians were rather well informed about what happened in the Nordic states, even though such articles tended to be short and published in the second half of the external news column.

Important political measures such as the dissolution of the union between Sweden and Norway in 1905 or the Russification of Finland were covered in detail and one could consider that this approach reflected the readers' interest towards these topics. Nevertheless, events that took place in Transylvania sometimes cast a shadow over foreign news, especially as newspapers are usually focused on the present.

Actually this represents another characteristic of the articles published by the three Romanian periodicals. Habitually, the news they report on is recent and the amount of historical information about the Nordic countries is negligible. Another consequence of this tendency is the fact that the fame of a number of the Northern 'personalities' (mainly 
writers and explorers) mentioned in some articles published by Foaie pentru minte, inimă şi literatură, Familia or Gazeta de Transilvania has not survived posterity.

Both the quantitative and the qualitative analyses converge to the conclusion that $19^{\text {th }}$ century Transylvanians had a lot of information about the Nordic countries' internal affairs and about their involvement in the continent's problems. The Northern monarchs' marriages, divorces or deaths, the issues raised sometimes by the succession to the throne, the speeches held by various representatives in front of their legislative assemblies, the laws that were promulgated in Sweden, Denmark, Norway or Finland, the Nordic countries' participation to international congresses or conferences, and their reaction to various international conflicts are just a few of the topics that were covered by the Transylvanian press during the studied period. Bilateral relations between Transylvania or Romania, on the one hand, and the Nordic countries, on the other hand, were also brought to the public's attention and their unfolding was watched with a lot of interest by the periodicals' readers. Furthermore, from a cultural point of view, the translations of literary works authored by Northerners enriched Transylvanians' knowledge about the Nordic countries and the Nordic writers' stands against different forms of national oppression was praised by Romanian journalists.

In order to complete the image that Romanian inhabitants of Transylvania had of the Nordic countries it is necessary to note that they did not perceive this area as a remote and inaccessible land. On the contrary, for them, these four countries were a part of Europe and their arguments had various sources: geography, politics, culture, travel writing.

In conclusion, in the $19^{\text {th }}$ century, Transylvanians' image of the Nordic countries is well shaped and has mainly positive connotations. Moreover, the amount of information they had at their disposal was rather large and capable of preserving their representations of Sweden, Denmark, Norway and Finland. In consequence, a careful scrutiny of historical sources proves that in spite of their different political and cultural backgrounds and disregarding the geographical distance that separates them, Transylvania and the Nordic countries were still able to know and appreciate one another in the $19^{\text {th }}$ century. 


\section{List of tables}

Table 1: Distribution of articles about the Nordic countries published in Foaie pentru minte, inimă şi literatură by country and by news category .... 100 Table 2: Number of articles about Lapland or Iceland and number of statistics published in Foaie pentru minte, inimă şi literatură 100 Table 3: Distribution of articles about the Nordic countries published in Familia by country and by news category 101

Table 4: Number of articles about Lapland or Iceland and number of statistics published in Familia..... 101

Table 5: Distribution of articles about the Nordic countries published in Gazeta de Transilvania by country and by news category 101 Table 6: Number of articles about Lapland or Iceland and number of statistics published in Gazeta de Transilvania. 102 Table 7: Yearly distribution of news about the Nordic countries published in Gazeta de Transilvania. 103 Table 8: Distribution of news about the Nordic countries published in Gazeta de Transilvania by column 103 


\section{References}

\section{A. Primary sources}

Familia. Foaie enciclopedică şi beletristică cu ilustrațiuni. Pesta-Oradea: 18651906.

Foaie pentru minte, inimă şi literatură. Braşov: 1838-1865.

Gazeta de Transilvania. Braşov: 1838-1919.

\section{B. Books and articles}

Boicu, L., V. Cristian and Gh. Platon, eds. România în relațiile internaționale 1699-1939. Iaşi: Junimea, 1980.

Calafeteanu, Ion and Cristian Popişteanu, eds. Politica externă a României: dicționar cronologic. Bucureşti: Editura Ştiințifică şi Enciclopedică, 1986.

Ciobanu, Veniamin. Carol al XII-lea şi românii. Iaşi: Domino, 1999.

Familia. Foaie enciclopedică şi beletristică cu ilustrațiuni 1865-1906. Indice bibliografic. 2 vols. Cluj: 1974.

Gemil, Tahsin. Țările române în contextul politic internațional (1621-1672). Bucureşti: Editura Academiei Republicii Socialiste România, 1979.

Hurdubețiu, Ion. Istoria Suediei. Bucureşti: Editura Ştiințifică şi Enciclopedică, 1985.

Ionaşcu, Ion, Petre Bărbulescu and Gheorghe Gheorghe, eds. Relațiile internaționale ale României în documente (1368-1900). Culegere selectivă de tratate, acorduri, convenții şi alte acte cu caracter internațional. Bucureşti: Editura Politică, 1971.

Lozovan, Eugen. “De la Mer Baltique à la Mer Noire." In Die Araber in der alten Welt. Zweiter Band. Bis zur Reichstrennung, ed. Franz Altheim and Ruth Stiehl, 524-554. Berlin: Walter De Gruyter \& Co, 1965.

---. “Doina et saga. Parallèles épiques roumano-scandinaves." In Actes du $4 e$ Congrès des Romanistes Scandinaves dédiés à Holger Sten: Revue Roumane, 207214. Numéro Spécial 1, 1967.

Marica, George Em. Foaie pentru minte, inimă şi literatură. Bibliografie analitică, cu un studiu monografic. Bucureşti: Editura pentru literatură, 1969.

Matei, Horia C. and others. Istoria României în date. Bucureşti: Editura Enciclopedică Română, 1971.

Soerensen, H. "Studiile româneşti în țările scandinave." In Analele Ştiințifice ale Universității "Al. I. Cuza" din Iaşi, New Series, Section III, Tom VI (1960), Fasc. II, Supplement: 57-60. 